Politechnika Śląska

\title{
Koncepcja klastra edukacyjnego dla ksztaltowania i rozwoju przedsiębiorczości akademickiej
}

Od czerwca 2009 roku na terenie województwa śląskiego jest realizowany duży projekt pod nazwą: „START - program promocji przedsiębiorczości w uczelniach wyższych województwa śląskiego". Projekt ten jest współfinansowany przez Unię Europejską ze środków Europejskiego Funduszu Społecznego w ramach Programu Operacyjnego Kapitał Ludzki. W projekcie bierze udział sześć wiodących uczelni województwa śląskiego: Politechnika Śląska (lider projektu), Akademia Ekonomiczna w Katowicach, Akademia Techniczno-Humanistyczna w Bielsku-Białej, Politechnika Częstochowska, Uniwersytet Śląski w Katowicach oraz Śląska Wyższa Szkoła Zarządzania im. gen. Jerzego Ziętka w Katowicach.

Cele projektu są następujące:

- podniesienie poziomu kreatywności, transferu wiedzy i postaw przedsiębiorczych wśród studentów i doktorantów,

- promowanie kreatywności i przedsiębiorczości wśród studentów oraz pracowników akademickich uczelni wyższych województwa śląskiego,

- usprawnienie procesów powstawania nowych firm opartych na pomysłach studentów, absolwentów i pracowników akademickich uczelni wyższych województwa śląskiego.

W każdym cyklu zostaną przeprowadzone szkolenia i warsztaty dla tysiąca studentów. Ideą szkoleń jest przekonanie studentów do stworzenia swoich biznesplanów. Pod kierunkiem trenerów studenci przygotują plany biznesowe i zdobędą wiedzę z zakresu przedsiębiorczości. Jury konkursu „START - pomysł na biznes” wyłoni najlepsze biznesplany, nagrodą zaś będzie preinkubacja i coaching.

\section{Struktura zarządzania projektem START}

Przedmiotem artykułu jest analiza struktur, w ramach których jest realizowany projekt START. Na ryc. 1 przedstawiono strukturę zarządzania w tym projekcie.

Na strukturę organizacyjną projektu START składają się:

- Komitet Sterujący - będący organem podejmującym strategiczne decyzje dotyczące projektu; w jego skład wchodzą rektorzy zaangażowanych uczelni,

- Biuro Programu wraz z koordynatorem projektu - zapewniające prawidłowe wdrażanie programu w obszarach funkcjonalnych, takich jak: finanse, komunikacja i metodologia oraz prowadzące sekretariat programu,

- menedżer programu - odpowiadający za zarządzanie procesami merytorycznymi w ramach projektu, wybrany z grona zewnętrznych ekspertów lub firm profesjonalnie zarządzających projektami rozwoju gospodarczego, jako neutralny animator interakcji wewnątrz zaangażowanych uczelni i pomiędzy nimi,

- 7 punktów kontaktowych - stanowiących centrum procesów merytorycznych realizowanych w każdej z uczestniczących uczelni oraz w Zespole Szkół Wyższych w Rybniku. 
Ryc. 1. Struktura zarządzania w projekcie START

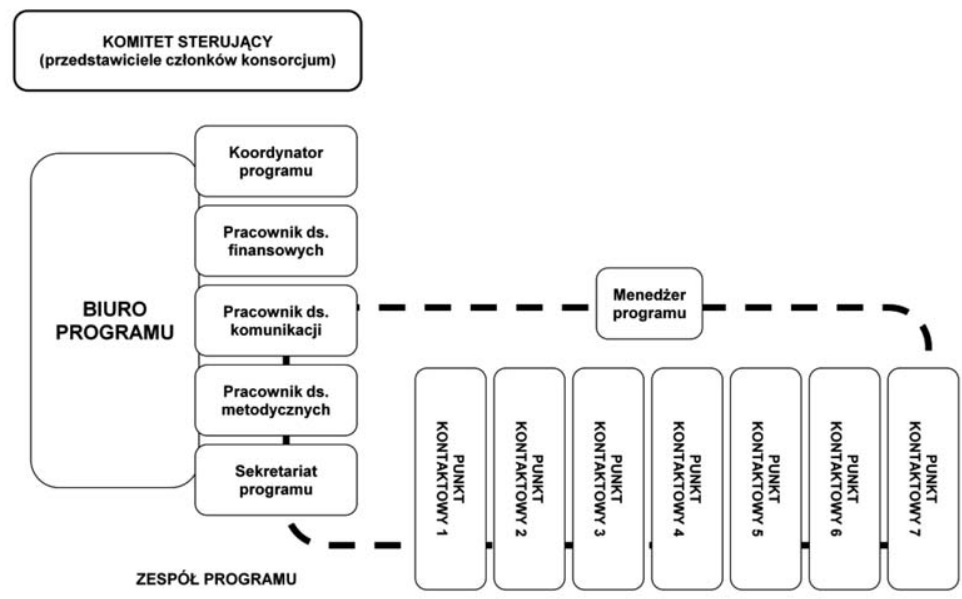

W Biurze Projektu pracuje osoba ds. metodycznych, pracownik ds. komunikacji, pracownik ds. finansowych i sekretarz, a nadzór nad tymi pracami sprawuje koordynator projektu. Jest on jednocześnie kierownikiem projektu w Politechnice Śląskiej. Na każdej uczelni działa punkt kontaktowy. Zostały one utworzone przy Biurach Karier, dzięki czemu w projekcie są wykorzystywane umiejętności pracowników biur, a także szerokie kontakty, co jest szczególnie ważne w tworzeniu START.FORUM. Nad spójną realizacją wszystkich zadań projektowych czuwa menedżer projektu, wyłoniony w trybie przetargu.

Przed przystąpieniem do analizy struktury warto wskazać zakres działań poszczególnych pracowników Biura Projektu. Komitet Sterujący, koordynator programu, menedżer programu, pracownik Biura Projektu ds. finansowych oraz osoby obsługujące sekretariat programu tworzą strukturę zarządzania projektem. Menedżer programu, pracownik Biura Projektu ds. komunikacji, pracownik Biura Projektu ds. metodycznych, osoby obsługujące sekretariat programu oraz pracownicy punktów kontaktowych tworzą zespół merytoryczny projektu. Biuro Projektu zostało utworzone przy instytucji lidera konsorcjum, tj. przy Politechnice Śląskiej. Lider konsorcjum zatrudnia pracowników Biura Projektu.

Zarządzanie projektem START przebiega następująco:

- zarządzanie finansowe i administracja konsorcjum projektowego prowadzone są przez Politechnikę Śląską jako lidera konsorcjum, zgodnie z zasadą partnera wiodącego, na warunkach określonych dla Programu Operacyjnego Kapitał Ludzki. Za zadania te odpowiada koordynator projektu, wspierany przez pracownika Biura Programu ds. finansowych oraz osoby obsługujące Sekretariat Programu,

- zarządzanie procesami merytorycznymi START zostanie powierzone neutralnemu menedżerowi.

Zadania menedżera to:

- stworzenie platformy koordynacji i komunikacji działań pomiędzy Punktami Kontaktowymi i Biurem Programu na rzecz efektywnej i skutecznej realizacji procesów merytorycznych START,

- kierowanie pracami merytorycznymi w ramach projektu; odpowiedzialność za te prace menedżer będzie ponosił przed Komitetem Sterującym (złożonym z rektorów uczelni tworzących konsorcjum), 
- ponoszenie odpowiedzialności za prawidłową i terminową realizację zadań zapisanych w aplikacji projektowej,

- nawiązywanie i podtrzymywanie kontaktów strategicznych dla programu START,

- ponoszenie odpowiedzialności za osiagnięcie założonych wskaźników realizacji projektu,

- zapewnienie profesjonalnego kierowania procesami merytorycznymi w ramach programu, zgodnie z wytyczoną metodologią i planem działania,

- zapewnienie neutralności w zarządzaniu procesami merytorycznymi programu i w komunikacji pomiędzy punktami kontaktowymi.

Menedżera projektu można odwołać decyzją Komitetu Sterującego. Menedżerowi podlegać będą: pracownik Biura Projektu ds. komunikacji, pracownik Biura Projektu ds. metodycznych, osoby obsługujące Sekretariat Projektu oraz pracownicy Punktów Kontaktowych.

Zadania pracownika ds. finansowych:

- zarządzanie finansowe,

- administrowanie konsorcjum projektowym prowadzonym przez Politechnikę Śląską - lidera konsorcjum - zgodnie z zasadą partnera wiodącego, na warunkach określonych dla PO KL,

- monitorowanie przebiegu projektu, w tym przyjmowanie i weryfikowanie okresowych sprawozdań merytorycznych i finansowych,

- przygotowywanie wniosków o płatność,

- utrzymywanie kontaktów z instytucją wdrażającą w kwestiach finansowych,

- przygotowywanie raportów z realizacji projektu.

Zadania pracownika ds. komunikacji:

- utrzymywanie bieżących kontaktów z mediami, przygotowywanie artykułów prasowych, notatek, treści do strony internetowej,

- kontakty ze sponsorami,

- stworzenie rozpoznawalnej w regionie identyfikacji wizualnej programu,

- efektywna i skuteczna promocja programu oraz komunikacja z beneficjentami ostatecznymi, środowiskiem biznesowym oraz społecznością regionu,

- bieżące wykonywanie ogólnych materiałów informacyjnych promujących projekt (plakaty, ulotki, pocztówki, długopisy, prezentacje),

- przygotowanie prezentacji dotyczącej programu START,

- zapewnienie spójnej komunikacji wewnętrznej i zewnętrznej.

Zadania pracownika ds. metodycznych:

- zapewnienie spójności metodologicznej projektu oraz bieżące monitorowanie i ocena modułów szkoleniowych i doradczych programu,

- organizacja szkoleń (kryteria wyboru ekspertów, ustalenie tematyki szkoleń),

- merytoryczne przygotowanie wykładów gościnnych,

- identyfikacja ekspertów realizujących poszczególne moduły szkoleniowe,

- przygotowanie przewodnika „START. Przedsiębiorczość Akademicka”,

- ocena szkoleń i warsztatów,

- opracowanie regulaminu konkursu oraz nadzór i wsparcie dla partnerów podczas jego realizacji.

Zadania sekretarza programu:

- przygotowanie dokumentacji technicznej do postępowania w sprawie zamówień publicznych,

- archiwizacja dokumentacji projektu, nadzór nad dokumentacją lidera oraz dokumentacją partnerów, która jest przekazywana do lidera, 
- terminowe dostarczanie dokumentacji do Instytucji Pośredniczącej (Urząd Marszałkowski),

- przygotowanie umów z pracownikami Biura Projektu, ekspertami, coachami, trenerami, autorami przewodnika,

- zapewnienie skutecznego administrowania programem, zgodnie z wytyczoną metodologią i planem działania.

\section{Struktura projektu START klastrem edukacyjnym}

Czy struktura projektu START jest klastrem? Jakie warunki musi spełniać, aby być klastrem? Dlaczego budowanie klastrów jest istotne? - na te pytania próbuje odpowiedzieć dalsza część artykułu.

Najczęściej przywoływana w literaturze przedmiotu definicja klastra wg M.E. Portera mówi, że klastry to geograficzne koncentracje powiązanych ze sobą przedsiębiorstw, wyspecjalizowanych dostawców, usługodawców, przedsiębiorstw o powiązanych gałęziach przemysłu, a także instytucji stowarzyszonych, np. uniwersytetów, agencji standaryzacji, stowarzyszeń handlowych, w szczególnych obszarach, które konkurują, ale również współpracują ze sobą.

Krytycznymi elementami sukcesu klastrów wg przewodnika A Practical Guide to Cluster Developement są przede wszystkim:

- partnerstwo w sieci-80\%,

- innowacyjne technologie - ponad $70 \%$,

- kapitał ludzki - ponad 70\%,

- infrastruktura - ok. $40 \%$,

- obecność dużych firm - ok. $40 \%$,

- przedsiębiorczość - ok. $35 \%$,

- dostęp do źródeł finansowania - ok. 30\%.

Literatura przedmiotu wyróżnia cechy klastrów, które charakteryzowałyby klastry edukacyjne. Według Ch. Ketelsa są to:

- bliskość geograficzna,

- powiązania (ukierunkowanie na wspólny cel),

- interakcje,

- liczba podmiotów.

Według obecnej wiedzy autorki, pojęcie klastra edukacyjnego jest utożsamiane z siecią powiązań. Najczęściej spotykane są klastry tworzone przez przedsiębiorstwa. Definicje, cechy, modele klastrów zostały sformułowane głównie poprzez przedsiębiorstwa i na ich potrzeby. Teoretyczne uwarunkowania tworzenia i funkcjonowania klastrów nie wykluczają możliwości tworzenia klastrów edukacyjnych.

Na ryc. 2 przedstawiono strukturę zarządzania w projekcie START w powiązaniu z czynnikami sukcesu klastra. Partnerstwo w sieci jest naturalnym elementem realizacji projektu. Punkty Kontaktowe stale współpracują z Biurem Programu. Są to powiązania zarówno formalne, jak i nieformalne. Z jednej strony każda uczelnia wykorzystuje swój potencjał i doświadczenia związane z przedsiębiorczością akademicką (Biura Karier, Akademickie Inkubatory Przedsiębiorczości) - jest autonomiczna. Z drugiej strony w całym projekcie obowiązują jednakowe procedury, np. regulamin przystąpienia i procedura przyjęcia do projektu. Kolejny element związany z partnerstwem w sieci to konkurencja, która zawsze w klastrach występuje. W tym przypadku - dość nietypowo - każdy podmiot klastra realizuje te same zadania i opiekuje się swoimi studentami. Nie ma więc sytuacji, w której uczelnia A prowadzi lepszą promocję i odbiera studentów uczelni B. Każda z uczelni musi się rozliczyć ze swoich wskaźników. W przypadku, gdy np. student ma pomysł na biznes, którego realizacja wymaga 
specjalistycznych konsultacji, a jego uczelnia nie ma takich możliwości, to kieruje go na inną uczelnię konsorcjum. Ten wymiar partnerstwa jest szczególnie ważny w realizacji projektu. Transfer kompetencji stanowi wartość dodaną projektu.

Istotą projektu nie jest tworzenie nowych technologii. Pojawiają się one jedynie w pomysłach biznesowych studentów i mogą być przez nich wykorzystywane, jednak sam klaster nie jest technologiczny, a edukacyjny.

Ryc. 2. Struktura zarządzania w projekcie START w powiązaniu z elementami sukcesu klastra

\section{ELEMENTY SUKCESU KLASTRA}

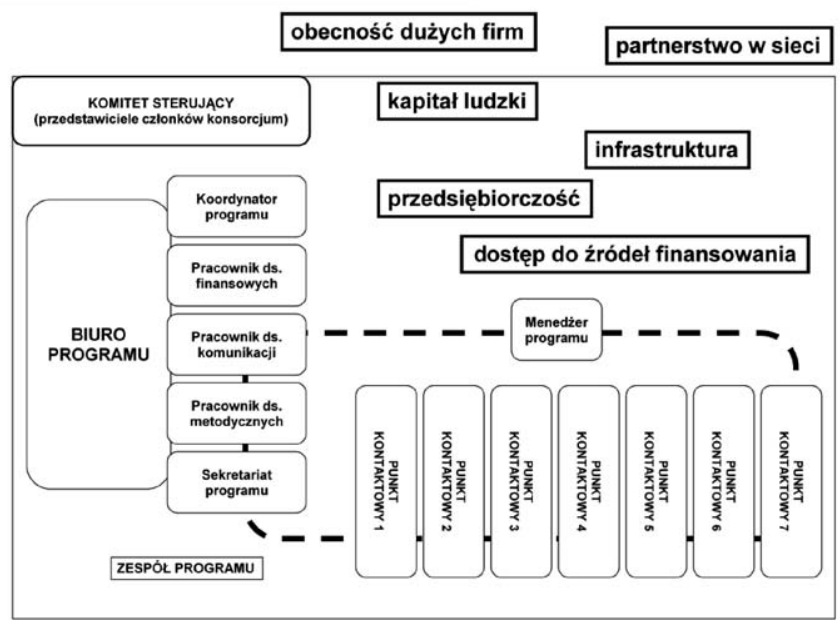

Kapitał ludzki jest także ściśle związany z partnerstwem w sieci. Bez udziału ludzi, ich wiedzy, kompetencji i doświadczenia żadna inicjatywa nie mogłaby być zrealizowana. Powodzenie realizacji klastra w dużej mierze zależy od kreatywności pracowników, ich elastyczności i chęci współpracy poza ustalonymi procedurami. Warto w tym miejscu zwrócić uwagę na podmioty wchodzące w skład klastra - to uczelnie, których struktury są bardzo rozbudowane, a procedury zawiłe i nieuniknione. Klaster START, który jest realizowany w sztywnych strukturach, musi więc dostosować się do barier strukturalnych i formalnych. Sztuką jest np. synchronizacja obiegu dokumentów w odpowiednim czasie, przy obecności sześciu uczestników projektu, którzy pracują w różnych miastach. Powodzenia klastra zależy zatem od skutecznego i kreatywnego zespołu, który zna, rozumie i chce pracować w strukturach uczelni.

Infrastruktura nie jest tworzona od podstaw, stanowi bazę projektu. Każda z uczelni ma odpowiednio wyposażone Biura Karier, dysponuje salami wykładowymi, sprzętem i zapleczem technicznych. Wyposażenie Punktów Kontaktowych i Biura Projektu ze środków Unii Europejskiej stanowi uzupełnienie istniejącego wyposażenia.

Obecność dużych firm w projekcie START jest związana z funkcjonowaniem START.FORUM, którego podmioty przedstawia ryc. 3. START.FORUM służy wymianie doświadczeń. Trudno bowiem uczyć przedsiębiorczości i sugerować założenie własnej działalności bez zaplecza praktycznego. Teoretyczne rozważania nie są istotne, ważny jest kontakt z coachami, ludźmi biznesu, małymi przedsiębiorcami, którzy dopiero weszli na rynek, a także z dużymi korporacjami.

Projekt jest współfinansowany przez Unię Europejską ze środków Europejskiego Funduszu Społecznego. Nie ma bariery finansowej w realizacji tych działań. Jeśli się pojawiają, to wynika to jedynie z ograniczeń wniosku, w którym zostały zaplanowane wydatki. 
Ryc. 3. Podmioty START.FORUM

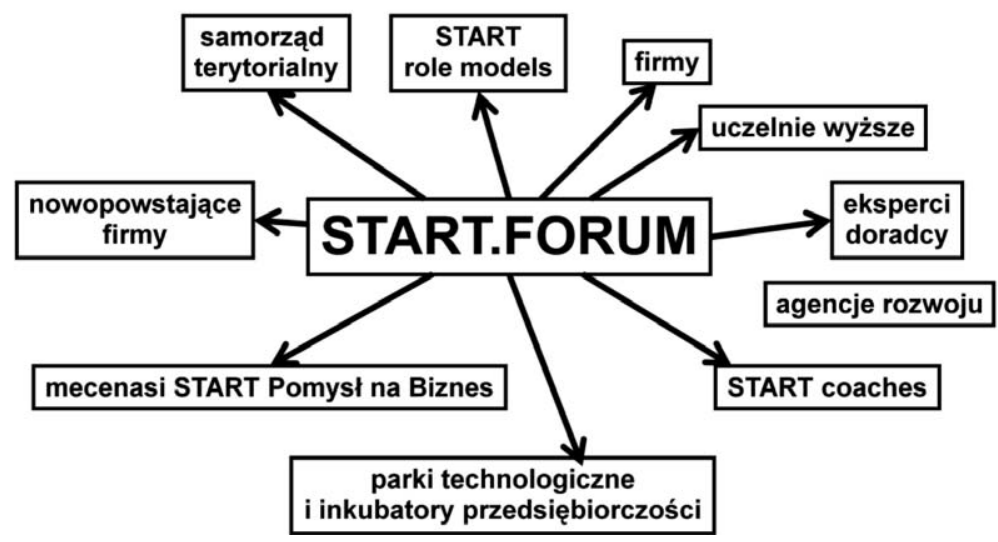

\section{Czy spelnione są cechy klastrów wg Katelsa?}

Bliskość geograficzna - tak, chociaż większość informacji i tak jest przekazywana drogą internetową bądź telefoniczną. Organizacja wspólnych przedsięwzięć: konferencji czy dni otwartych jest łatwiejsza, gdy partnerzy znajdują się w jednym województwie.

Powiązania i interakcje warto ująć wspólnie. Uczelnie są powiązane na mocy umowy konsorcjum. To wymusza interakcje i partnerstwo, które omówiono wcześniej. Liczba podmiotów to sześć uczelni. Jest to optymalna liczba w skali województwa, ponieważ zbyt duża liczba uczelni wywołałaby ogrom formalności. Utraciłaby się wówczas idea wspólnego działania, a lider koncentrowałby się jedynie na koordynacji działań i tworzeniu procedur, bez których zapanowałby chaos dokumentacyjny.

\section{Ograniczenia przy tworzeniu klastrów edukacyjnych na przykładzie projektu START}

W ostatniej części artykułu opisano ograniczenia przy tworzeniu klastrów edukacyjnych. Po pół roku realizacji projektu można wymienić kilka ograniczeń i zagrożeń dla powodzenia realizacji klastra. Jest to także sygnał do znalezienia środków zaradczych.

Główne ograniczenia przy tworzeniu klastrów edukacyjnych to:

- brak chęci współpracy,

- autonomia - samodzielność partnerów,

- społeczny opór przed zmianami,

- sztywne struktury organizacyjne,

- procedury administracyjne uczelni i Instytucji Pośredniczącej, zbytnia biurokracja,

- finanse.

To, czy partnerzy współpracują, zależy od kapitału ludzkiego, poszczególnych pracowników i ich dobrej woli. Sztywne struktury i hierarchia uczelni są pewnym ograniczeniem, ale jeśli pracownicy skutecznie się komunikują i chcą działać wspólnie, to działania w strukturach administracji można zaplanować z wyprzedzeniem. Jeśli natomiast pracownicy np. nie odpisują sobie wzajemnie na wiadomości, nie chcą poszerzyć swojej wiedzy i nie wykazują się inicjatywą, to nigdy nie będzie między nimi odpowiedniej współpracy. Wtedy projekt nie będzie klastrem. Skłonność do współpracy zależy od samych ludzi, ale też od kultury zarządzania, zwyczajów i zasad panujących w organizacji. Z drugiej strony istnieje autonomia partnerów. Klaster, w którym każdy z partnerów realizuje te same zadania, jest nietypowy. Lider bowiem narzuca schematy i procedury postępowania dla wszystkich, ale każda uczelnia 
wykorzystuje własne doświadczenia w kształtowaniu przedsiębiorczości akademickiej. Wypracowanie kompromisu pomiędzy koniecznością sformalizowania działań w ramach projektu a pomysłowością partnerów i ich chęciami wdrożenia interesujących rozwiązań jest kluczem funkcjonowania klastra.

Społeczny opór przed zmianami jest barierą wielu działań, szczególnie w sektorze publicznym. Jednostki samorządowe muszą prowadzić skutecznie public relations, aby móc wdrożyć zmiany. Nie zawsze racjonalne argumenty są wystarczające; emocjonalne podejście do wielu spraw społecznych nie wpływa pozytywnie na racjonalizację zadań. W przypadku omawianego projektu opór przed zmianami nie jest przeszkodą. Studenci otrzymują pakiet szkoleń, mogą uzyskać i pogłębić wiedzę. Wzięcie udziału w projekcie nie ma żadnych negatywnych konsekwencji. Nie ma też konieczności zakładania własnej firmy, co dla niektórych jest zbyt dużym wyzwaniem.

Sztywne struktury administracyjne i biurokracja są ograniczeniem i czasami trudno je ominąć. Nawet jeśli zespół jest dobrze dobrany i zarządzany, to trudności formalno-prawne potrafią bardzo przedłużyć działania. Mimo starań nie zawsze bowiem można planować te działania z właściwym wyprzedzeniem. Problem polega jednak jeszcze na tym, iż w projekcie są tworzone zespoły zadaniowe, których członkowie nierzadko byli dyrektorami i kierownikami w innych strukturach. Dlatego nie zawsze potrafią oni przezwyciężyć swoje przyzwyczajenia do pracy w charakterze lidera zespołu i podjąć się w projekcie pracy zespołowej w sposób zadaniowy i w strukturze poziomej.

Opisany przykład projektu START ma wiele cech, dzięki którym można nazwać go klastrem edukacyjnym. Dopiero jednak po zrealizowaniu projektu będzie można ocenić, czy faktycznie tak było. Niewątpliwie tworzenie klastrów edukacyjnych jest łatwiejsze poprzez realizację projektów, niż tworzenie ich w ramach istniejących już struktur.

\section{Literatura}

1. Ketels Ch., 2003, The development of cluster concept - present experiences and further developments, Duisburg.

2. Porter M.E., 1998, On competition, Harvard Business School Press, Boston.

3. Sainsbury L., A Practical Guide to Cluster Development, Raport przygotowany dla Departamentu Handlu i Przemystu oraz angielskich Regionalnych Agencji Rozwoju przez firmę Ecotec Research \& Consulting.

\section{The Concept of Cluster Education for the Development and Improvement of Academic Enterprises}

The paper tries to answer the question of building educational clusters. It highlights as an example the structure of the START Project, which helps in the development of academic enterprise projects. It presents the advantages and disadvantages of clusters. Partners have the same assignments and they exchange their competencies. The paper also presents structures of clusters where partners have different assignments. One of the aims of clusters is to find a compromise wherever possible. 